\title{
KAJIAN SWOT PROSPEK DAN STRATEGI PENGEMBANGAN UNIT USAHA PRODUK INOVASI KAMPUS INFORMASI GEOSPASIAL DI UNIVERSITAS UDAYANA
}

\author{
T.B. Kusmiyarti ${ }^{1}$, R. Suyarto ${ }^{2}$, dan I.K. Sardiana ${ }^{3}$
}

\begin{abstract}
ABSTRAK
Pengembangan jiwa entrepreneurship di kalangan sivitas akademika saat ini menjadi penting untuk memacu kemampuan berwirausaha memanfaatkan hasil inovasi intelektual kampus. Penelitian bertujuan untuk mengidentifikasi factor internal dan eksternal sebagai acuan pemilihan strategi untuk mengembangkan unit usaha inivasi intelektual kampus PPUPIK-Informasi Geospasial di Universitas Udayana. Analisis yang dilakukan menggunakan analisis SWOT dan matrik EFI dan EFE. Kedua analisis akan focus untuk menetapkan strategi pengembangan unit usaha PPUPIK-Informasi Geospasial. Hasil penelitian menunjukkan bahwa unit usaha PPUPIK-Informasi Geospasial Universitas Udayana berada pada posisi sel 4, yang diperoleh dari nilai EFI sebesar 3,01 yang menunjukkan posisi unit usaha kuat, sedangkan nilai EFE 2,44 yang berarti posisi eksternalnya sedang. Dengan demikian strategi yang harus diterapkan adalah strategi stability dan berhati-hati terhadap faktor internal maupun eksternal.
\end{abstract}

Kata kunci : analisis SWOT unit usaha inovasi intelektual kampus, informasi geospasial, pengembangan, strategi, prospek

\section{PENDAHULUAN}

Kebutuhan data dan informasi kebumian atau yang lebih dikenal dengan informasi geospasial dirasakan semakin penting, baik oleh institusi pemerintah, swasta, perguruan tinggi maupun masyarakat umum. Informasi tersebut sangat diperlukan dalam mengelola sumber daya alam, penyusunan perencanaan wilayah, tata guna lahan dan rencana tata ruang. Selain itu, informasi geospasial juga dapat digunakan untuk menentukan garis batas wilayah, pertanahan, industri, kepariwisataan, kesehatan masyarakat serta pertahanan dan keamanan. Ketersediaan informasi geospasial yang akurat dan terpercaya dapat meningkatkan efektivitas pengambilan keputusan (Baja, 2012).

Namun demikian, untuk memperoleh informasi geospasial yang berkualitas memerlukan dukungan perangkat keras (hardware) dan perangkat lunak (software) yang biayanya sangat mahal serta sumberdaya manusia berkompeten dalam bidang tersebut. Sejalan dengan kebutuhan informasi geospasial yang semakin meningkat, maka kebutuhan sumberdaya manusia mahir di bidang tersebut semakin banyak pula. Secara nasional, kebutuhan sumberdaya manusia tersebut mencapai kisaran 50.000 orang (Abidin, 2017).

\footnotetext{
${ }^{1}$ Fakultas Pertanian Universitas Udayana, tatihartanto@ymail.com

${ }^{2}$ Fakultas Pertanian Universitas Udayana, rsuyarto@yahoo.co.id

${ }^{3}$ Fakultas Pertanian Universitas Udayana, ketutsardiana@unud.ac.id
} 
Untuk pengembangan teknologi dalam bidang pengelolaan informasi geospasial, Universitas Udayana bekerjasama dengan Badan Informasi Geospasial (BIG) mendirikan Pusat Pengembagan Infrastruktur Data Spasial (PPIDS) di Universitas Udayana dan telah ditetapkan dengan Keputusan Rektor Nomor 3659/UN22/TI/2014 tertanggal 2 Desember 2014. PPIDS Unud dilengkapi dengan server beserta aplikasinya dan dukungan sumber daya manusia yang ahli pada bidangnya seperti ilmu tanah, Teknik Informatika, remote sensing (penginderaan jauh), Teknik Lingkungan, dan pariwisata dan lalin-lain. Tugas pokok dan fungsi PPIDS adalah penyediaan data dan informasi geospasial; penyebarluasan data dan informasi geospasial; penelitian dan pengembangan ilmu pengetahuan serta teknologi di bidang informasi geospasial; penyelenggaraan kegiatan peningkatan dan pengembangan kompetensi sumber daya manusia terkait informasi geospasial. Namun demikian, dalam mengemban fungsi tersebut PPIDS tidak didukung sumber dana yang memadai sehingga belum berjalan secara optimal. Oleh sebab itu, perlu upaya perolehan pendapatan (income generating) mandiri untuk menunjang operasional tersebut.

Memperhatikan kebutuhan SDM informasi geospasial yang begitu luas, dan sumberdaya yang tersedia di PPIDS Unud, baik SDM maupun perangkat penunjang yang sangat memadai membawa pemikiran menjadikan PPIDS sebagai unit usaha Inovasi intelektual kampus. Produk yang ditawarkan oleh unit usaha Informasi Geospasial (PPUPIK-IG) Universitas Udayana berupa jasa pelatihan kompetensi aplikasi software, analisis maupun manajemen data geospasial, dan jasa pengerjaan/pengolahan berbagai data dan informasi tematik geospasial. Unit usaha ini diharapkan dapat mempercepat proses pengembangan budaya kewirausahaan di perguruan tinggi, menunjang otonomi kampus perguruan tinggi melalui perolehan pendapatan mandiri atau bermitra, memberikan kesempatan dan pengalaman kerja di bidang IG kepada mahasiswa dan alumni, mendorong berkembangnya budaya pemanfaatan hasil riset perguruan tinggi bagi masyarakat, dan dapat membina kerjasama dalam bidang IG dengan instansi pemerintah ataupun sektor swasta termasuk pihak industri dan sektor pemasaran. Selain itu, unit ini dapat membantu masyarakat (user) memperoleh produk IG secara lebih mudah dan murah.

Produk IbKIK-IG memiliki pangsa pasar yang sangat luas, baik instansi pemerintah, swasta, mahasiswa maupun masyarakat umum. Instansi pemerintah diantaranya staf BPN, Bappeda, Kehutanan, Pertanian, Kelautan, kependudukan, kesehatan masyarakat, dan lain-lain. Pihak swasta diantaranya konsultan perencana, pengembang, landscape, dan lain-lain. Masyarakat umum adalah masyarakat yang memerlukan data dan peta tematik seperti batas wilayah, tataguna lahan, dan lain-lain . Produk tersebut sangat diperlukan dalam pekerjaan perencanaan wilayah, tata ruang, Detail Enginering Design (DED), penelitian geospasial, proyek kawasan industri, pariwisata, pertanian, dan lain-lain.

Usaha jasa pelatihan dan produk IG tersebut sudah mulai dirintis oleh PPIDS UNUD tahun 2016, yaitu dengan menyelenggarakan pelatihan berbayar tentang kompetensi operasional software informasi geospasial. Kegiatan tersebut ternyata mendapatkan respon yang sangat positif dari pengguna (user) ditandai oleh jumlah peserta pelatihan yang mencapai 20 orang. Sementara itu, untuk produk pengembangan IG (peta tematik), pada tahun 2016 PPIDS Unud bekerjasama dengan Bappeda Kabupaten Tabanan mengerjakan perencanaan Agrotechnopark Kabupaten Tabanan. Keberadaan lembaga/unit yang menawarkan jasa di bidang pengelolaan informasi geospasial di Provinsi Bali sangat terbatas, malah dapat dikatakan tidak ada. Oleh karena itu, tidak ditemukan kompetitor untuk unit usaha ini. Keadaan ini membuat usaha layanan jasa pada bidang informasi geospasial cukup menjanjikan. Dengan SDM dan fasilitas yang tersedia pada PPIDS Universitas Udayana, PPUPIK Informasi Geospasial ini diharapkan dapat memacu perkembangannya di masa mendatang. 
Pengembangan unit usaha PPUPIK-Informasi Geospasial memerlukan kajian yang lebih mendalam untuk memahami faktor-faktor yang mendukung ataupun menghambat. Langkah ini penting dilakukan untuk mendukung keberhasilan unit usaha yang akan dikembangkan. Berdasarkan uraian diatas maka untuk menjamin kinerja dan keberlangsungan unit usaha ini perlu dilakukan kajian mendalam tentang kekuatan, kelemahan, ancaman dan peluang yang mempengaruhi keberlanjutan unit usaha IbKIK_IG Universitas Udayana. Kajian akan dilakukan dengan analisis SWOT. Fungsi dari analisis SWOT dan strsategi kompetitif adalah untuk menganalisa mengenai kekuatan,kelemahan serta keunggulan kompetitif yang dimiliki perusahaan/unit usaha yang dilakukan melalui analisa terhadap kondisi internal perusahaan, serta analisa mengenai peluang dan ancaman yang dihadapi unit usaha. Hasil dari analisis SWOT digunakan sebagai acuan untuk menentukan strategi kompetitif untuk menentukan langkah-langkah efisiensi agar dapat meningkatkan margin keuntungan secara signifikan dan produktifitas dapat ditingkatkan.

\section{METODE PELAKSANAAN}

Penelitian dilakukan pada bulan September - November 2018. Lokasi penelitian adalah Unit Usaha Inovasi Kampus Informasi Geospasial Universitas Udayana, Gedung Agrokomplek Lt. 4., Jl. PB. Sudirman Denpasar Bali. Analisis dalam penelitian ini adalah dengan menggunakan analisi swot, dimana metode ini menunjukkan kinerja perusahaan dengan menentukan kombinasi faktor internal dan eksternal. analisis swot membandingkan antara faktor internal, yaitu kekuatan (stregth), dan kelemahan (weakness). dengan faktor eksternal yaitu peluang (opportunity), dan ancaman (threats). Faktor internal dimasukan ke dalam matrik yang disebut matrik faktor EFI (Evaluasi Faktor Internal)). Faktor eksternal dimasukan ke dalam matrik yang disebut matrik faktor EFE (Evaluasi Faktor Eksternal). Setelah matrik faktor strategi internal dan eksternal selesai disusun kemudian hasilnya dimasukan ke dalam model kualitatif yaitu matrik swot untuk merumuskan strategi kompetitif perusahaan.

\section{HASIL DAN PEMBAHASAN}

Analisis SWOT mencakup upaya-upaya untuk mengenali kekuatan, kelemahan, peluang, dan ancaman yang menentukan kinerja perusahaan/Unit Usaha. Informasi eksternal mengenai peluang dan ancaman diperoleh dari banyak sumber, termasuk pelanggan, dokumen pemerintah, pemasok, kalangan perbankan, rekan di perusahaan lain. Banyak perusahaan menggunakan jasa lembaga pemindaian untuk memperoleh keliping surat kabar, riset di internet, dan analisis tren-tren domestik dan global yang relevan. Selanjutnya Rangkuti (2004) menjelaskan bahwa analisis SWOT adalah identifikasi berbagai faktor secara sistematis untuk merumuskan strategi perusahaan. Analisis ini didasarkan pada logika yang dapat memaksimalkan kekuatan dan peluang, namun secara bersamaan dapat meminimalkan kelemahan dan ancaman. Proses pengambilan keputusan strategi selalu berkaitan dengan pengembangan misi, tujuan, strategi dan kebijakan perusahaan. Dengan demikian, perencanaan strategi harus menganalisa faktor faktor strategi perusahaan dalam kondisi saat ini.

\subsection{Identifikasi Lingkungan Internal dan Eksternal}

Kerangka SWOT hasil identifikasi lingkungan internal dan eksternal unit usaha PPUPIKInformasi Geospasial Universitas Udayana disajikan dalam Tabel 1 berikut.

\begin{tabular}{|c|c|}
\hline KEKUATAN & KELEMAHAN \\
\hline $\begin{array}{l}\text { Adanya kebijakan satu peta yang telah } \\
\text { ditetapkan oleh pemerintah RI }\end{array}$ & $\begin{array}{lcr}\text { Informasi } & \text { geospasial } & \text { berkualitas } \\
\text { memerlukan perangkat lunak dan perangkat }\end{array}$ \\
\hline
\end{tabular}




\begin{tabular}{|c|c|}
\hline & keras dengan biaya yang mahal \\
\hline $\begin{array}{l}\text { Produk informasi geospasial memiliki } \\
\text { pangsa pasar yang sangat luas, baik instansi } \\
\text { pemerintah, swasta, mahasiswa maupun } \\
\text { masyarakat umum. }\end{array}$ & \begin{tabular}{lll} 
Dalam & penyelenggaraan & \multicolumn{2}{c}{ Informasi } \\
Geospasial & (IG) sangat dibutuhkan \\
teknologi tinggi dan SDM IG yang \\
kompeten
\end{tabular} \\
\hline $\begin{array}{l}\text { Ketersediaan jumlah SDM IG di Unud } \\
\text { yang memadai }\end{array}$ & $\begin{array}{l}\text { Kinerja unit usaha belum optimal karena } \\
\text { dana yang terbatas }\end{array}$ \\
\hline $\begin{array}{l}\text { Memilki orientasi untuk pengembangan } \\
\text { tridharma Perguruan Tinggi }\end{array}$ & $\begin{array}{l}\text { Keterbatasan fasilitas pendukung dan } \\
\text { manajemen usaha yang belum optimal }\end{array}$ \\
\hline an teknologi IG, UNUD & \\
\hline & \\
\hline $\begin{array}{l}\text { Perkembangan teknologi informasi } \\
\text { geospasial yang sangat cepat, sangat } \\
\text { mendukung perkembangan unit usaha/ } \\
\text { kemajuan teknologi }\end{array}$ & Munculnya pesaing baru \\
\hline $\begin{array}{l}\text { Hubungan yang baik dengan instansi } \\
\text { pemerintah dan suasta }\end{array}$ & $\begin{array}{l}\text { Regulasi yang tidak membolehkan instansi } \\
\text { pemerintah/usaha pemerintah untuk } \\
\text { mengikuti tender proyek-proyek pemerintah }\end{array}$ \\
\hline $\begin{array}{l}\text { Luasnya pengguna data dan informasi } \\
\text { geospasial }\end{array}$ & $\begin{array}{l}\text { Kebutuhan SDM bidang informasi } \\
\text { geospasial luas }\end{array}$ \\
\hline $\begin{array}{l}\text { Kebutuhan informasi kebumian/informasi } \\
\text { geospasial semakin penting }\end{array}$ & $\begin{array}{l}\text { Jasa penyediaan informasi geospasial } \\
\text { memerlukan biaya yang mahal }\end{array}$ \\
\hline
\end{tabular}

Tabel 1. Kerangka SWOT Unit Usaha PPUPIK-Informasi Geospasial

\subsection{Evaluasi Faktor Internal (Matrik EFI)}

Di bawah ini merupakan hasil dari pengolahan matrik evaluation faktor internal. Untuk menentukan rating dan bobot merupakan hasil konsultasi dengan anggota tim unit usaha PPUPIK-informasi Geospasial. Dan untuk penilaian nilai skor dikalikan rata-rata rating dengan rata-rata bobotnya. Hal yang sama dilakukan untuk menetapkan matrik EFI.

Faktor internal merupakan lingkungan internal yang terdiri dari kekuatan dan kelemahan yang ada di dalam organisasi tetapi biasanya tidak dalam pengendalian jangka pendek dari manajemen puncak. Lingkungan internal terdiri dari keuangan dan Akuntansi, SDM, Pemasaran, Operasi, dan Penelitian/Pengembangan. Hasil pengolahan matrik evaluasi factor internal pada unit usaha IbKIKInformasi Geospasial disajikan pada Tabel 2.

Tabel 2. Matriks Evaluasi Faktor Internal

\begin{tabular}{|l|l|l|l|}
\hline \multicolumn{1}{|c|}{ FAKTOR-FAKTOR STRATEGIS INTERNAL } & BOBOT & RATING & $\begin{array}{c}\text { BOBOT } \\
\text { x } \\
\text { RATING }\end{array}$ \\
\hline KEKUATAN & & & \\
\hline $\begin{array}{l}\text { Adanya kebijakan satu peta yang telah ditetapkan } \\
\text { oleh pemerintah RI }\end{array}$ & 0,10 & 3 & 0,3 \\
\hline $\begin{array}{l}\text { Produk informasi geospasial memiliki pangsa pasar } \\
\text { yang sangat luas, baik instansi pemerintah, swasta, } \\
\text { mahasiswa maupun masyarakat umum. }\end{array}$ & 0,23 & 4 & 0.92 \\
\hline $\begin{array}{l}\text { Ketersediaan jumlah SDM IG di Unud yang } \\
\text { memadai }\end{array}$ & 0,11 & 3 & 0,33 \\
\hline $\begin{array}{l}\text { Memilki orientasi untuk pengembangan tridharma } \\
\text { Perguruan Tinggi }\end{array}$ & 0,07 & 2 & 0.14 \\
\hline
\end{tabular}




\begin{tabular}{|l|l|l|l|}
\hline $\begin{array}{l}\text { Untuk pengembangan teknologi IG, UNUD } \\
\text { bekerjasama dengan BIG }\end{array}$ & 0,05 & 2 & 0,10 \\
\hline KELEMAHAN & & & \\
\hline $\begin{array}{l}\text { Informasi geospasial berkualitas memerlukan } \\
\text { perangkat lunak dan perangkat keras dengan biaya } \\
\text { yang mahal }\end{array}$ & 0,14 & 2 & 0.28 \\
\hline $\begin{array}{l}\text { Dalam penyelenggaraan Informasi Geospasial (IG) } \\
\text { sangat dibutuhkan teknologi tinggi dan SDM IG } \\
\text { yang kompeten }\end{array}$ & 0,13 & 3 & 0.39 \\
\hline $\begin{array}{l}\text { Kinerja unit usaha belum optimal karena dana yang } \\
\text { terbatas }\end{array}$ & 0,03 & 2 & 0,06 \\
\hline $\begin{array}{l}\text { Keterbatasan fasilitas pendukung dan manajemen } \\
\text { usaha yang belum optimal }\end{array}$ & 0,07 & 3 & 0,21 \\
\hline SDM pendukung yang trampil terbatas & 0,07 & 4 & 0,28 \\
\hline TOTAL & 1,0 & & 3,01 \\
\hline
\end{tabular}

\subsection{Evaluasi Faktor Eksternal (EFE)}

Lingkungan eksternal meliputi semua kejadian dan berbagai factor di luar perusahaan yang memiliki potensi mempengaruhi jalannya perusahaan, dengan demikian faktor-faktor ini harus diperhitungkan oleh perusahaan pada saat akan membuat keputusan, karena lingkungan eksternal ini merupakan faktor-faktor yang di luar kendali yang mempengaruhi pilihan perusahaan untuk menetapkan arah dan tindakan (Pearce at al., 2013; Duncan, 1972). Hasil pengolahan matrik Evaluasi Faktor eksternal unit usaha PPUPIK-Informasi Geospasial disajikan pada Tabel 3.

Tabel 3. Matrik Evaluasi Faktor Eksternal (EFE) Unit Usaha IbKIK-Informasi Geospasial

\begin{tabular}{|c|c|c|c|}
\hline $\begin{array}{ll}\text { FAKTOR-FAKTOR } & \text { STRATEGIS } \\
\text { EKSTERNAL } & \\
\end{array}$ & BOBOT & RATING & $\begin{array}{l}\text { BOBOT } x \\
\text { RATING }\end{array}$ \\
\hline \multicolumn{4}{|l|}{ PELUANG } \\
\hline $\begin{array}{l}\text { Perkembangan teknologi } \\
\text { geospasial yang sangat cepat }\end{array}$ & 0,21 & 2 & 0,42 \\
\hline $\begin{array}{l}\text { Hubungan yang baik dengan instansi } \\
\text { pemerintah dan suasta }\end{array}$ & 0,09 & 4 & 0,36 \\
\hline $\begin{array}{l}\text { Luasnya pengguna data dan informasi } \\
\text { geospasial }\end{array}$ & 0,10 & 3 & 0,3 \\
\hline $\begin{array}{l}\text { Kebutuhan informasi kebumian/informasi } \\
\text { geospasial semakin penting }\end{array}$ & 0,07 & 2 & 0,14 \\
\hline \multicolumn{4}{|l|}{ ANCAMAN } \\
\hline Munculnya pesaing baru & 0,10 & 2 & 0,2 \\
\hline $\begin{array}{l}\text { Regulasi yang tidak membolehkan instansi } \\
\text { pemerintah/usaha pemerintah untuk } \\
\text { mengikuti tender proyek-proyek } \\
\text { pemerintah }\end{array}$ & 0,06 & 2 & 0,12 \\
\hline $\begin{array}{l}\text { Kebutuhan SDM bidang informasi } \\
\text { geospasial luas }\end{array}$ & 0,16 & 3 & 0,48 \\
\hline $\begin{array}{l}\text { Jasa penyediaan informasi geospasial } \\
\text { memerlukan biaya yang mahal }\end{array}$ & 0,21 & 2 & 0,42 \\
\hline TOTAL & 1,00 & & 2,44 \\
\hline
\end{tabular}

Berdasarkan nilai EFI sebesar 3,01 dan nilai EFE sebesar 2,44, kemudian ditetapkan posisi unit usaha melalui diagram model untuk strategi korporat (Diagram 1) (Rangkuti, 2004). 


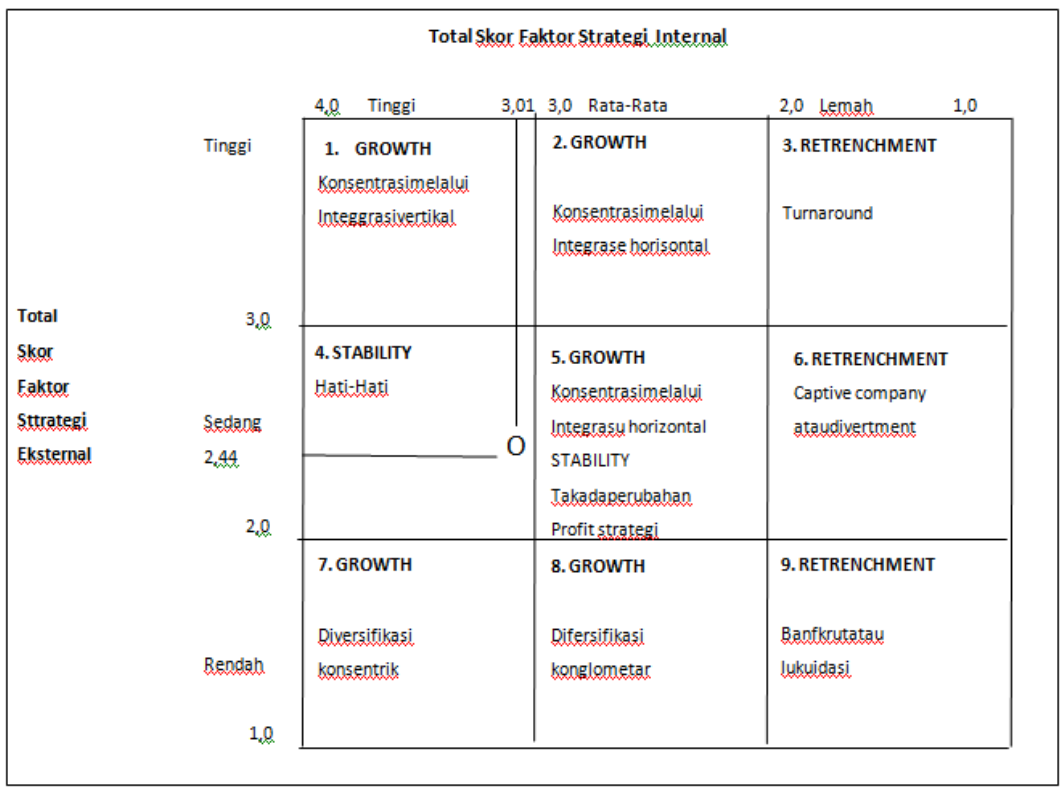

Gambar 1. Diagram Model untuk Strategi Korporat

Unit usaha PPUPIK-Informasi Geospasial berada pada sel 4, ini berarti strategi yang diterapkan adalah strategi stability dan tetap berhati-hati dengan adanya faktor internal maupun eksternal.

\section{KESIMPULAN DAN SARAN}

\subsection{Kesimpulan}

Faktor internal unit usaha PPUPIK-Informasi Geospasial adalah (1) Informasi geospasial berkualitas memerlukan perangkat lunak dan perangkat keras dengan biaya yang mahal, Dalam penyelenggaraan Informasi Geospasial (IG) sangat dibutuhkan teknologi tinggi dan SDM IG yang kompeten, Kinerja unit usaha belum optimal karena dana yang terbatas, Keterbatasan fasilitas pendukung dan manajemen usaha yang belum optimal, SDM pendukung yang trampil terbatas (Kelemahan); dan (2) adanya kebijakan satu peta yang telah ditetapkan oleh pemerintah RI, produk informasi geospasial memiliki pangsa pasar yang sangat luas, baik instansi pemerintah, swasta, mahasiswa maupun masyarakat umum, ketersediaan jumlah SDM IG di Unud yang memadai, memilki orientasi untuk pengembangan tridharma Perguruan Tinggi, dan untuk pengembangan teknologi IG, UNUD bekerjasama dengan BIG (kekuatan).

\subsection{Saran}

Penumbuhan jiwa entrepreneurship di kalangan sivitas akademika di lingkungan Universitas Udayana telah dilakukan dengan berbagai metode dan model. Sosialisasi dan pelatihan tentang entrepreneurship sebaiknya dilakukan lebih banyak lagi dengan peserta yang lebih luas.

\section{UCAPAN TERIMA KASIH}

Ucapan terima kasih disampaikan kepada Kemenristek Dikti atas bantuan pendanaan kegiatan P2UPIK dan Lembaga Penelitian dan Pengabdian kepada Masyarakat (LPPM) Universitas Udayana. 


\section{DAFTAR PUSTAKA}

Hunger, J. David. and Wheelen, Thomas L. 2000. Manajemen Srategis. Prentice Hall.

Abidin, Z.A.2017. Human Resource Development Geospatial information for national development needs and facing global challenges. Annual Scientific Forum 2017. Indonesian Surveyor Association. Pekanbaru.

Baja, S. 2012. Perencanaan Tata Guna Lahan dalam Pengembangan Wilayah. Pendekatan Spasial dan Aplikasinya. Yogyakarta. Penerbit Andi.

Duncan, R. B. 1972. Characteristics of Organizational Environments and Precieved Environmental Uncertainty. Administrative Science Quaterly, Vol. 17.

Pierce II, Jhon. A, Robinson Jr., Richard B. 2013. Manajemen strategis: Formulasi, Implementasi, dan Pengendalian. Buku I. Edisi 12. Jakarta. Salemba Empat.

Sardiana, IK., BRT Putri, IG Suranjaya, NLR Purnawan. 2015. Pengembangan Kewirausahaan di Universitas Udayana. Ngayah: Majalah Aplikasi IPTEKS 6 (1)

Rangkuti, F. 2004. Analisis SWOT Teknik Membedah Kasus Bisnis. Jakarta. PT. Gramedia Pustaka Utama. 